\title{
Hubungan indeks massa tubuh dengan rasio TG/HDL pada pasien diabetes mellitus tipe 2
}

\author{
Andrico Napolin Lumbantobing ${ }^{1 \star}$, Suandy ${ }^{1}$, Ilham Akbar Lubis ${ }^{1}$ \\ ${ }^{1}$ Fakultas Kedokteran, Kedokteran Gigi, dan Ilmu Kesehatan Universitas Prima Indonesia
}

\begin{abstract}
ABSTRAK
Gambaran dislipidemia pada DM tipe 2 yang paling sering ditemukan adalah peningkatan kadar TG dan penurunan kadar HDL. Penelitian ini bertujuan menganalisis hubungan indeks massa tubuh dengan rasio TG/HDL pada pasien diabetes mellitus tipe 2. Penelitian ini merupakan penelitian observasional analitik dengan pendekatan cross-sectional. Populasi pada penelitian ini adalah seluruh rekam medis pasien diabetes melitus yang tercatat dalam rekam medis RS Royal Prima dari April sampai Mei 2021. Metode pengambilan sampel dilakukan dengan metode total sampling. Jumlah sampel yang terlibat sebanyak 100 orang. Data diperoleh dari rekam medis pasien diabetes mellitus. Data dianalisis menggunakan uji Chi-Square. Hasil penelitian menunjukkan bahwa usia paling banyak terkena diabetes melitus tipe II yang paling tinggi pada mortalitas usia 40-60 tahun berjumlah 51 orang. Sementara distribusi proporsi pasien diabetes melitus tipe II berdasarkan jenis kelamin yang paling banyak adalah laki-laki yaitu 64 orang. Hasil uji bivariat menunjukkan bahwa usia tidak berhubungan dengan indeks massa tubuh $(0,517)$. Demikian juga dengan hasil uji pada jenis kelamin, disimpulkan bahwa jenis kelamin juga tidak berhubungan dengan indeks massa tubuh $(0,683)$. Sedangkan kadar rasio TG/HDL paling tinggi adalah 3,6-4,5 dengan jumlah total 44 , sementara nilai rasio TG/HDL paling rendah adalah 1,1-2,5 dengan jumlah total 5 .
\end{abstract}

Kata kunci: diabetes melitus, indeks massa tubuh, TG/HDL

\begin{abstract}
The most common features of dyslipidemia in type 2 DM are increased TG levels and decreased HDL levels. This study analyzes the relationship between body mass index and the ratio of TG/HDL in patients with type 2 diabetes mellitus. This study is an analytical observational study with a cross-sectional approach. The population in this study were all medical records of diabetes mellitus patients recorded in the medical records of the Royal Prima Hospital from April to May 2021. The sampling method was conducted by the total sampling method. The number of samples was 100 people. Data were obtained from medical records of patients with diabetes mellitus. Data were analyzed using Chi-Square test. The results showed that the age most affected by type II diabetes mellitus with the highest mortality at the age of 40-60 years amounted to 51 people. Meanwhile, the distribution of the proportion of type II diabetes mellitus patients based on gender was mostly male, namely, 64 people. The results of the bivariate test showed that age was not associated with body mass index (0.517). Likewise, with the test results on gender, it was concluded that gender was also not related to body mass index (0.683). Meanwhile, the highest TG/HDL ratio was 3.6-4.5 with 44, while the lowest TG/HDL ratio was 1.1-2.5 with a total of 5 .
\end{abstract}

Keywords: diabetes mellitus, body mass index, TG/HDL

*Alamat korespondensi: holladoctor@gmail.com DOI: $10.34012 /$ jpms.v4i1.2283

\section{PENDAHULUAN}

Seratus juta orang di seluruh dunia menderita diabetes, menurut WHO, dan jumlahnya terus meningkat. Menurut penelitian pendaftaran sampel Indonesia tahun 2014, diabetes adalah penyebab kematian terbesar ketiga, terhitung 6,7\% dari semua kematian. ${ }^{1}$ Kategori penyakit metabolik yang dikenal sebagai diabetes mellitus (DM) ditandai dengan hiperglikemia karena kombinasi kelainan yang 
mempengaruhi fungsi insulin dan insulin. Sebanyak $90 \%$ penderita diabetes memiliki diabetes mellitus tipe 1, atau DMT2. ${ }^{2}$ Diperkirakan sebanyak 30,3 juta orang Amerika menderita diabetes, menurut penelitian CDC yang diterbitkan pada tahun 2017. ${ }^{3}$ Prevalensi diabetes global diperkirakan akan meningkat dari 425 juta orang (2017) berubah 629 juta (2045), menurut Federasi Diabetes Internasional (IDF) pada tahun 2017. Populasi Asia Tenggara diperkirakan akan tumbuh dari 82 juta (2017) menjadi 151 juta (2045), menurut PBB. Dengan perkiraan populasi 5,4 juta penderita diabetes pada tahun 2045, Indonesia menempati posisi ke-7 di dunia mengenai prevalensi diabetes. ${ }^{4}$ Terjadi perubahan metabolisme karbohidrat, lemak dan protein tubuh akibat penurunan kerja insulin atau sekresi insulin. Ketika sel-sel penghasil insulin dihancurkan, ini terjadi. Ketika insulin tidak ada dari tubuh, transportasi glukosa melintasi membran sel berkurang, mengakibatkan kelaparan di dalam sel dan peningkatan metabolisme lemak. ${ }^{5}$

Pasien dengan diabetes memiliki kadar HDL-C rendah dan trigliserida tinggi, yang keduanya merupakan tanda dislipidemia, yang dapat menyebabkan penyakit jantung. Sudah menjadi rahasia umum bahwa "diabetes trinity" memiliki HDL-C rendah, LDL-C rendah, dan partikel LDL padat kecil dalam darah penderita diabetes (DM). Sebagai hasil dari glikolisis LDL, penderita diabetes juga dapat mengalami pembentukan plak aterosklerotik. ${ }^{6}$ Pada orang dengan pradiabetes, proses aterotrombotik mendominasi, membuat manajemen glikemik tidak cukup untuk menghindari kejadian kardiovaskular. Penyakit vaskular aterotrombotik dikaitkan dengan kadar kolesterol total dan LDL-C tinggi, dan HDL-C rendah, yang dapat diturunkan dengan pengobatan yang sesuai. Aterosklerosis sering dikaitkan dengan dislipidemia. Frekuensi kejadian kardiovaskular menurun dalam beberapa penelitian ketika kadar LDL-C berkurang. ${ }^{7}$

Dislipidemia adalah kelainan metabolisme lemak yang ditandai dengan peningkatan maupun penurunan kadar lemak dalam plasma. Kelainan kadar lemak yang paling utama adalah kenaikan kadar kolesterol total, kolesterol LDL, kenaikan kadar trigliserida serta penurunan kadar. Dislipidemia merupakan salah satu faktor risiko dari kejadian penyakit tidak menular. WHO memperkirakan pada tahun 2020 PTM akan menyebabkan 73\% kematian dan 60\% kesakitan di seluruh dunia. ${ }^{89}$ Penelitian menunjukkan bahwa penderita diabetes mempunyai trigliserida dan LDL tinggi, serta HDL rendah, dan variasi minimum dalam komposisi kolesterol LDL mereka, yang semuanya berkontribusi pada perkembangan aterosklerosis. ${ }^{10}$ Salah satu faktor terpenting yang berkontribusi terhadap aterosklerosis adalah kombinasi kolesterol HDL, LDL dan trigliserida. Triad lipid mengacu pada lipid HDL, LDL, dan trigliserida. ${ }^{11}$

WHO memperkirakan pada tahun 2015 lebih dari 1,9 milyar orang dewasa diatas 18 tahun mengalami kelebihan berat tubuh (overweight) dan lebih dari 600 juta orang mengalami obesitas. ${ }^{12}$ Data Riskesdas 2018 menunjukkan prevalensi obesitas sentral pada usia $\geq 15$ tahun meningkat dari 26,6\% pada tahun 2013 menjadi 31,0\% pada tahun 2018, dengan prevalensi terbesar di Provinsi Sulawesi Utara yaitu $42.5 \% \cdot{ }^{13}$ Resiko timbulnya diabetes melitus meningkat dengan naiknya indeks massa tubuh lebih dari normal. Kelebihan berat badan dapat membuat sel-sel tubuh tidak sensitif terhadap insulin (resisten insulin). ${ }^{14}$ Insulin berperan dalam meningkatkan ambilan glukosa di banyak sel dan dengan cara ini juga insulin mengatur metabolisme karbohidrat, sehingga jika terjadi resistensi insulin oleh sel, maka kadar gula di dalam darah juga dapat terganggu. ${ }^{15}$ Gambaran dislipidemia pada DM tipe 2 yang paling sering ditemukan adalah peningkatan kadar TG dan penurunan kadar HDL. ${ }^{16}$ Penelitian ini bertujuan menganalisis hubungan indeks massa tubuh dengan rasio TG/HDL pada pasien diabetes mellitus tipe 2.

\section{METODE}

Penelitian ini merupakan penelitian observasional analitik dengan pendekatan cross-sectional. Populasi pada penelitian ini adalah seluruh rekam medis pasien diabetes melitus yang tercatat dalam 
rekam medis RS Royal Prima dari April sampai Mei 2021. Metode pengambilan sampel dilakukan dengan metode total sampling. Jumlah sampel yang terlibat sebanyak 100 orang. Data diperoleh dari rekam medis pasien diabetes mellitus. Data yang telah diperoleh akan dimasukkan dan diolah dalam software pengolah data dengan menggunakan program computer SPSS. Data dianalisis menggunakan metode analisis univariat (analisis deskriptif) yang bertujuan untuk menjelaskan atau mendeskripsikan karakteristik setiap variabel penelitian. Selain itu, uji bivariat juga dilakukan untuk melihat hubungan antara variabel bebas dan variabel terikat dengan menggunakan uji kemaknaan Chi-Square.

\section{HASIL}

Penelitian ini dilaksanakan di bagian Rekam Medik Rumah Sakit Umum (RSU) Royal Prima. Pada tabel 1 dapat dilihat bahwa usia paling banyak terkena diabetes melitus tipe 2 pada mortalitas usia 40-60 tahun berjumlah 51 orang, sementara yang paling rendah pada usia mortalitas < 40 tahun berjumlah 3 orang. Distribusi pasien diabetes melitus tipe 2 berdasarkan jenis kelamin paling banyak adalah lakilaki 64 orang $(64,0 \%)$, sisanya adalah perempuan 36 orang (36,0\%).

Distribusi pasien diabetes melitus berdasarkan kadar gula darah yang terbanyak adalah $>200 \mathrm{mg} / \mathrm{dl}$ dengan persentase $64.0 \%$ dan yang paling sedikit adalah $<200 \mathrm{mg} / \mathrm{dl}$ (36.0\%). Distribusi pasien diabetes melitus berdasarkan kadar trigliserida yang terbanyak adalah $>150 \mathrm{mg} / \mathrm{dl}$ dengan persentase $82.0 \%$ dan yang paling sedikit adalah $<150 \mathrm{mg} / \mathrm{dl}$ (18.0\%). Distribusi proporsi pasien diabetes melitus berdasarkan kadar HDL yang terbanyak adalah $<40 \mathrm{mg} / \mathrm{dl}$ dengan persentase $66.0 \%$ dan proporsi yang paling sedikit adalah $>40 \mathrm{mg} / \mathrm{dl}$ (34.0\%). Distribusi pasien diabetes melitus berdasarkan kadar LDL yang terbanyak adalah $<130 \mathrm{mg} / \mathrm{dl}$

Tabel 1. Karakteristik responden

\begin{tabular}{|c|c|c|}
\hline Karakteristik & $\mathrm{n}$ & $\%$ \\
\hline \multicolumn{3}{|l|}{ Usia } \\
\hline$<40$ tahun & 8 & 8,0 \\
\hline $40-60$ tahun & 75 & 75,0 \\
\hline$>60$ tahun & 17 & 17,0 \\
\hline \multicolumn{3}{|l|}{ Jenis kelamin } \\
\hline Laki-laki & 64 & 64,0 \\
\hline Perempuan & 36 & 36,0 \\
\hline \multicolumn{3}{|l|}{ Kadar gula darah } \\
\hline$<200 \mathrm{mg} / \mathrm{dl}$ & 36 & 36.0 \\
\hline$>200 \mathrm{mg} / \mathrm{dl}$ & 64 & 64.0 \\
\hline \multicolumn{3}{|l|}{ Kadar trigliserida } \\
\hline$<150 \mathrm{mg} / \mathrm{dl}$ & 18 & 18.0 \\
\hline$>150 \mathrm{mg} / \mathrm{dl}$ & 82 & 82.0 \\
\hline \multicolumn{3}{|l|}{ Kadar LDL } \\
\hline$<40 \mathrm{mg} / \mathrm{dl}$ & 66 & 66.0 \\
\hline$>40 \mathrm{mg} / \mathrm{dl}$ & 34 & 34.0 \\
\hline \multicolumn{3}{|l|}{ Kadar LDL } \\
\hline$<130 \mathrm{mg} / \mathrm{dl}$ & 53 & 53.0 \\
\hline$>130 \mathrm{mg} / \mathrm{dl}$ & 47 & 47.0 \\
\hline \multicolumn{3}{|c|}{ Indeks Massa Tubuh } \\
\hline$<25 \mathrm{~kg} / \mathrm{m}^{2}$ & 39 & 39.0 \\
\hline$>25 \mathrm{~kg} / \mathrm{m}^{2}$ & 61 & 61.0 \\
\hline
\end{tabular}
dengan persentase $53.0 \%$ dan yang paling sedikit adalah $>130 \mathrm{mg} / \mathrm{dl}$ (47.0\%). Distribusi pasien diabetes melitus berdasarkan IMT yang terbanyak adalah $>25 \mathrm{~kg} / \mathrm{m}^{2}$ dengan persentase $61.0 \%$ dan yang paling sedikit adalah $<25 \mathrm{~kg} / \mathrm{m}^{2}(39.0 \%)$.

Tabel 2. Hasil analisis bivariat

$\begin{array}{lccc}\text { Karakteristik } & \begin{array}{c}\text { Indeks Massa Tubuh } \\ <25 \mathrm{~kg} / \mathrm{m}^{2}\end{array} & \mathrm{p} 25 \mathrm{~kg} / \mathrm{m}^{2} & \mathrm{p} \\ \text { Usia } & & & \\ <40 \text { tahun } & 4 & 4 & \\ \text { 40-60 tahun } & 29 & 46 & 0,517 \\ \quad>60 \text { tahun } & 6 & 11 & \\ \text { Jenis kelamin } & & & \\ \text { Laki-laki } & 24 & 40 & 0,683 \\ \text { Perempuan } & 15 & 21 & \\ \text { TG/HDL } & & & \\ 1,1-2,5 & 2 & 3 & \\ 2,6-3,5 & 11 & 22 & \\ 3,6-4,5 & 19 & 25 & 0,699 \\ 4,6-5,5 & 7 & 9 & \\ >5,5 & 0 & 2 & \end{array}$

Hasil uji bivariat menunjukkan bahwa usia tidak berhubungan dengan indeks massa tubuh di mana nilai $\mathrm{p}$ lebih besar dari 0,05. Demikian juga dengan hasil uji pada jenis kelamin, disimpulkan bahwa jenis kelamin juga tidak berhubungan dengan indeks massa tubuh $(p=0,683)$. Sedangkan kadar rasio TG/HDL paling tinggi adalah 3,6-4,5 dengan jumlah total 44 , sementara nilai rasio TG/HDL paling rendah adalah 1,1-2,5 dengan jumlah total 5 . Bila dilihat dari hasil uji Chi-Square test didapat nilai p sebesar 0,699, dapat disimpulkan bahwa nilai $\mathrm{p}$ tidak signifikan karena $\mathrm{p}>0,05$. 


\section{PEMBAHASAN}

Hasil penelitian menunjukkan bahwa usia paling banyak terkena diabetes melitus tipe II yang paling tinggi pada mortalitas usia 40-60 tahun berjumlah 51 orang. Sementara yang paling rendah pada usia mortalitas $<40$ tahun berjumlah 3 orang. Sementara distribusi proporsi pasien diabetes melitus tipe II berdasarkan jenis kelamin yang paling banyak adalah laki-laki yaitu 64 orang. Sedangkan yang paling rendah yaitu perempuan yaitu 36 orang. Penelitian yang dilakukan oleh Hakim \& Purwanti (2018) menyebutkan bahwa penderita DM tipe 2 sebagian besar berusia di atas 41 tahun. ${ }^{17}$ Usia yang lebih tua dapat berisiko karena kinerja fisiologis pada usia tersebut akan menurun dan tidak dapat mengontrol fungsi tubuh secara optimal, sehingga menurunkan resistensi insulin yang berujung pada tingginya kadar glukosa darah. ${ }^{18}$ Studi terdahulu menemukan bahwa wanita 2,35 kali lebih mungkin menderita DM tipe 2 dibandingkan pria. ${ }^{19}$ Perbedaan komposisi lemak tubuh dan kadar hormon seks mungkin menjadi alasan mengapa perempuan lebih berpotensi menderita DM dibandingkan laki-laki. ${ }^{14}$

Distribusi proporsi pasien diabetes melitus berdasarkan kadar gula darah yang terbanyak adalah $\geq$ $200 \mathrm{mg} / \mathrm{dl}$ dengan persentase $64.0 \%$ dan proporsi yang paling sedikit adalah $<200 \mathrm{mg} / \mathrm{dl}(36.0 \%)$. Faktor lain yang terkait dengan risiko diabetes adalah penderita polycystic ovarysindrome (PCOS), penderita sindrom metabolik memiliki riwayat toleransi glukosa terganggu (TGT) atau glukosa darah puasa terganggu (GDPT) sebelumnya, memiliki riwayat penyakit kardiovaskuler seperti stroke, PJK, atau peripheral arterial diseases (PAD), konsumsi alkohol, faktor stres, kebiasaan merokok, jenis kelamin, konsumsi kopi dan kafein. ${ }^{20}$ Terdapat korelasi bermakna antara obesitas dengan kadar glukosa darah, pada derajat kegemukan dengan IMT > 23 dapat menyebabkan peningkatan kadar glukosa darah menjadi 200mg. Keadaan yang ditandai dengan kenaikan kadar lemak darah (trigliserida > $250 \mathrm{mg} / \mathrm{dl}$ ). Terdapat hubungan antara kenaikan plasma insulin dengan rendahnya $\mathrm{HDL}(<35 \mathrm{mg} / \mathrm{dl})$ sering didapat pada pasien diabetes. ${ }^{21}$

Distribusi proporsi pasien diabetes melitus berdasarkan kadar trigliserida yang terbanyak adalah $\geq$ $150 \mathrm{mg} / \mathrm{dl}$ dengan persentase $82.0 \%$ dan proporsi yang paling sedikit adalah $<150 \mathrm{mg} / \mathrm{dl}(18.0 \%)$. Distribusi proporsi pasien diabetes melitus berdasarkan kadar HDL yang terbanyak adalah $<40 \mathrm{mg} / \mathrm{dl}$ dengan persentase $66.0 \%$ dan proporsi yang paling sedikit adalah $>40 \mathrm{mg} / \mathrm{dl}(34.0 \%)$. Distribusi proporsi pasien diabetes melitus berdasarkan kadar LDL yang terbanyak adalah $<40 \mathrm{mg} / \mathrm{dl}$ dengan persentase $66.0 \%$ dan proporsi yang paling sedikit adalah $>40 \mathrm{mg} / \mathrm{dl}(34.0 \%)$. Menurut penelitian yang lain menyakatan menunjukan bahwa IMT kategori normal terdapat 15 orang $(68,2 \%)$ dengan kondisi kadar trigliserida kategori normal dan 11 orang $(32,4 \%)$ dengan trigliserida kategori berlebih. Sedangkan IMT kategori berlebih terdapat 7 orang $(31,8 \%)$ dengan kadar trigliserida kategori normal dan 23 orang $(62,6 \%)$ dengan kadar trigliserida kategori berlebih. ${ }^{22}$

Penelitian lain menyatakan profil lipid didapatkan rata-rata kadar kolesterol total $164,74 \mathrm{mg} / \mathrm{dl}$ pada laki-laki dan 220,76 mg/dl pada perempuan. Rata-rata kadar HDL 34,26 mg/dl pada laki-laki dan 40,29 mg/dl pada perempuan, kadar LDL 107,09 mg/dl pada laki-laki dan 145,94 mg/dl pada perempuan, kadar trigliserida $119,03 \mathrm{mg} / \mathrm{dl}$ pada laki-laki dan $165,71 \mathrm{mg} / \mathrm{dl}$ pada perempuan. ${ }^{23}$ Berdasarkan penelitian lain diketahui bahwa dari 56 responden yang diteliti, terlihat bahwa yang terbanyak dengan kadar HDL kategori rendah yaitu berjumlah 29 orang (51,8\%), sisanya kategori normal berjumlah 27 orang (48,2\%). Berdasarkan hasil penelitian diketahui juga 73,91\% pasien memiliki kadar HDL di bawah normal. Didapatkan 79,41\% perempuan memiliki kadar HDL $\leq 50 \mathrm{mg} / \mathrm{dl}$ dan $68,57 \%$ laki-laki memiliki kadar HDL $\leq 40 \mathrm{mg} / \mathrm{dl}$. Hal sesuai dengan teori yang mengatakan bahwa gambaran dislipidemia pada DM tipe 2 yang paling sering adalah penurunan kadar HDL. ${ }^{24}$ Penelitian lain juga menyatakan didapatkan gambaran profil lipid pada penderita DM tipe 2 dengan hipertensi di RSD Mangusada dalam periode November 2018-April 2019. Profil lipid berupa HDL dan LDL memiliki angka status normal sebanyak 33 orang $(63,46 \%)$ dan dislipidemia sebanyak 19 orang 
(36,54\%). Profil lipid berupa kolesterol total dan trigliserida memiliki angka status normal yang lebih kecil dari angka status dislipidemia yaitu, masing-masing sebanyak 25 orang $(48,08 \%)$ dan 24 orang $(46,15 \%)$ dengan dislipidemia sebanyak 27 orang $(51,92 \%)$ dan 28 orang $(53,85 \%) .{ }^{25}$

Distribusi proporsi pasien diabetes melitus berdasarkan IMT yang terbanyak adalah $>25 \mathrm{~kg} / \mathrm{m}^{2}$ dengan persentase $61.0 \%$ dan proporsi yang paling sedikit adalah $<25 \mathrm{~kg} / \mathrm{m}^{2}(39.0 \%)$. Penelitian lain menyatakan Indeks Massa Tubuh tinggi sebanyak 3 orang (14,3\%), sedangkan pasien kadar Apolipoprotein B tinggi memiliki Index Massa Tubuh normal sebanyak 10 orang $(71,4 \%)$ dan pasien kadar Apolipoprotein B tinggi memiliki Index Massa Tubuh tinggi sebanyak 4 orang $(28,6 \%){ }^{26}$ Penelitian lain juga menyatakan diketahui bahwa dari 56 responden yang diteliti,terlihat bahwa yang terbanyak dengan IMT kategori berlebih sebanyak 30 orang $(53,6 \%)$ selebihnya didapatkan IMT kategori normal yaitu 26 orang (46,4\%). Responden yang memiliki kategori IMT normal merupakan distribusi tertinggi dengan presentasi 42,1\% dan kategori gemuk dengan presentasi 41,1\% merupakan distribusi terendah. ${ }^{27}$ Namun hasil studi yang dilakukan oleh Khusna (2016) menunjukkan hasil yang berbeda, IMT memiliki korelasi positif dengan tingkat sedang dengan rasio TG/HDL. Semakin tinggi IMT semakin tinggi juga rasio TG/HDL. ${ }^{28}$

Rendahnya kadar kolesterol HDL dan hipertrigliseridemia telah ditemukan berhubungan secara independen dan signifikan terhadap infark miokard/stroke pada pasien sindroma metabolik. Demikian juga, gabungan antara kadar glukosa puasa yang tinggi dengan rendahnya kolesterol HDL telah terbukti dapat digunakan sebagai prediksi munculnya penyakit jantung koroner. Dislipidemia pada pasien sindroma metabolik dapat disebabkan oleh kombinasi VLDL apoB-100 yang berlebih, penurunan katabolisme apoB, dan peningkatan katabolisme HDL-apo A-I. ${ }^{29}$

\section{KESIMPULAN}

Hasil penelitian menunjukkan bahwa usia paling banyak terkena diabetes melitus tipe II yang paling tinggi pada mortalitas usia 40-60 tahun berjumlah 51 orang. Sementara distribusi proporsi pasien diabetes melitus tipe II berdasarkan jenis kelamin yang paling banyak adalah laki-laki yaitu 64 orang. Hasil uji bivariat menunjukkan bahwa usia tidak berhubungan dengan indeks massa tubuh $(0,517)$. Demikian juga dengan hasil uji pada jenis kelamin, disimpulkan bahwa jenis kelamin juga tidak berhubungan dengan indeks massa tubuh $(0,683)$. Sedangkan kadar rasio TG/HDL paling tinggi adalah 3,6-4,5 dengan jumlah total 44 , sementara nilai rasio TG/HDL paling rendah adalah 1,1-2,5 dengan jumlah total 5 .

\section{REFERENSI}

1. Kementerian Kesehatan. Infodatin Diabetes Melitus. Jakarta: Pusat Data dan Informasi Kementerian Kesehatan RI; 2014.

2. Kalyani RR, Golden SH, Cefalu WT. Diabetes and Aging: Unique Considerations and Goals of Care. Diabetes Care [Internet]. 2017 Mar 10;40(4):440-3. Available from: https://doi.org/10.2337/dci17-0005

3. Gao HX, Regier EE, Close KL. Prevalence of and trends in diabetes among adults in the United States, 1988-2012. Vol. 8, Journal of diabetes. Australia; 2016. p. 8-9.

4. Artha IMJR, Bhargah A, Dharmawan NK, Pande UW, Triyana KA, Mahariski PA, et al. High level of individual lipid profile and lipid ratio as a predictive marker of poor glycemic control in type-2 diabetes mellitus. Vasc Health Risk Manag. 2019;15:149-57.

5. Krug EG. Trends in diabetes: sounding the alarm. Lancet [Internet]. 2016 Apr 9;387(10027):1485-6. Available from: https://doi.org/10.1016/S0140-6736(16)30163-5

6. Ginsberg HN, Elam MB, Lovato LC, Crouse 3rd JR, Leiter LA, Linz P, et al. Effects of combination lipid therapy in type 2 diabetes mellitus. N Engl J Med [Internet]. 2010/03/14. 2010 Apr 29;362(17):1563-74. Available from: https://pubmed.ncbi.nlm.nih.gov/20228404

7. Rabbani N, Godfrey L, Xue M, Shaheen F, Geoffrion M, Milne R, et al. Glycation of LDL by 
methylglyoxal increases arterial atherogenicity: a possible contributor to increased risk of cardiovascular disease in diabetes. Diabetes [Internet]. 2011/05/26. 2011 Jul;60(7):1973-80. Available from: https://pubmed.ncbi.nlm.nih.gov/21617182

8. Aekplakorn W, Taneepanichskul S, Kessomboon P, Chongsuvivatwong V, Putwatana P, Sritara P, et al. Prevalence of Dyslipidemia and Management in the Thai Population, National Health Examination Survey IV, 2009. J Lipids [Internet]. 2014/03/30. 2014;2014:249584. Available from: https://pubmed.ncbi.nlm.nih.gov/24800083

9. Ali Z, Alfatlawi W, Aldabagh A-G. Role of insulin dysfunction in development of dyslipidemia in type 2 diabetes mellitus (DM2). Int J Pharm Res. 2021 Jan 1;12(2).

10. Samatha P, Venkateswarlu M, Siva Prabodh V. Lipid profile levels in type 2 diabetes mellitus from the tribal population of Adilabad in Andhra Pradesh, India. J Clin Diagnostic Res. 2012;6(4 SUPPL. 2):593-6.

11. Gibson R. Principles Of Nutritional Assessment. New York: Oxford University Press; 2005.

12. Nuraini A, Murbawani EA. Hubungan Antara Ketebalan Lemak Abdominal Dan Kadar Serum High Sensitivity C-Reactive Protein (Hs-Crp) Pada Remaja. J Nutr Coll. 2019;8(2):81.

13. Kementerian Kesehatan RI. Riset Kesehatan Dasar Tahun 2018. Vol. 53, Kementerian Kesehatan RI. Jakarta; 2018.

14. Isnaini N, Hikmawati I. Pengaruh Indeks Masa Tubuh Terhadap Kadar Gula Darah Sewaktu. J Ilm Ilmu Kesehat [Internet]. 2016;14(1):65-71. Available from: http://jurnalnasional.ump.ac.id/index.php/medisains/article/download/1046/2133.

15. Guyton A, Hall J. Buku Ajar Fisiologi Kedokteran. 11th ed. Jakarta: EGC; 2008.

16. Ratnasari A, Indranila I, Retnoningrum D. Hubungan Antara Hba1C Dengan Kadar Hdl Pada Pasien Diabetes Melitus Tipe 2. Diponegoro Med J (Jurnal Kedokt Diponegoro). 2017;6(2):141-7.

17. Hakim DL, Purwanti OS. Hubungan tingkat sosial ekonomi: pendidikan, penghasilan, dan fasilitas dengan pencegahan komplikasi kronis pada penyandang diabetes melitus tipe 2 di Surakarta. Universitas Muhammadiyah Surakarta; 2018.

18. Jelantik IGMG, Haryati E. Hubungan Faktor Risiko Umur, Jenis Kelamin, Kegemukan Dan Hipertensi Dengan Kejadian Diabetes Mellitus Tipe II Di Wilayah Kerja Puskesmas Mataram. Media Bina Ilm [Internet]. 2017;53(9):21-5. Available from: http://www.elsevier.com/locate/scp

19. Herdianti. Determinan Kualitas Hidup Penderita DM Tipe 2 di RSUD Ajjappange. J Endur. 2017;2(1):74.

20. Harding A-H, Day NE, Khaw K-T, Bingham S, Luben R, Welsh A, et al. Dietary fat and the risk of clinical type 2 diabetes: the European prospective investigation of Cancer-Norfolk study. Am J Epidemiol. 2004 Jan;159(1):73-82.

21. Fatimah RN. Diabetes Melitus tipe 2. J Major. 2015;4(5):93-101.

22. Nanis A, Bakhtiar R. Dislipidemia Dengan Riwayat Pengobatan Tradisional: Studi Kasus Dengan Pendekatan Kedokteran Keluarga. J Kedokt Mulawarman. 2020 Dec 29;7:34.

23. Josten S, Mutmainnah, Hardjoeno. Profil Lipid Penderita Diabetes Mellitus Tipe 2. Indones J. 2006;13(1):20-2.

24. Koampa PH, Pandelaki K, Wongkar MCP. Hubungan indeks massa tubuh dengan profil lipid pada pasien diabetes melitus tipe 2. e-CliniC. 2016;4(1).

25. Sumertayasa INH, Agung A, Lestari W, Herawati S. HDL pada pasien Diabetes Mellitus tipe 2 dengan hipertensi di Rumah Sakit Daerah Mangusada, Badung tahun 2018-2019. 2020;11(3):1198-205.

26. Faisal M. Hubungan Kadar Small Dense LDL Dengan Derajat Retinopati Diabetika Pada Pasien Diabetes Mellitus Tipe 2. Universitas Sumatera Utara; 2018.

27. Nur M, Esfandiari F, Anggraeni S, Septian D. Hubungan Indeks Massa Tubuh Dengan Kadar Kolestrol Pada Pasien Diabetes Mellitus Tipe 2 Di Praktik Mandiri Dokter K. Hakikiyah Lampung Tengah. J Med Malahayati. 2020;4(1):1-8.

28. Khusna FH. Hubungan Indeks Massa Tubuh Dengan Rasio Trigliserida/High-Density Lipoprotein (TG/HDL) Pada Remaja. Universitas Diponegoro. Semarang; 2016.

29. Wahjuni S. Dislipidemia Menyebabkan Stress Oksidatif Ditandai Oleh Meningkatnya Malondialdehid. Denpasar: Udayana University Press; 2015. 